on locked antlers by Notz (1965).

One may only speculate on the frequency of occurrence of aggressive interactions between the two species. While their distribution shows considerable overlap in west-central North America (Hall and Kelson, 1959), habitat variability usually provides for effective ecological separation in the overlap zone. Ecological separation, however, appears to be less developed in the relatively flat northern Great Plains and foothills, and thus the species may come into direct contact frequently in southwestern Saskatchewan and adjacent Alberta and Montana.

Likewise, we can only speculate on the behavioural significance of such interactions. Even in a species such as the whitetail in which many thousands of conspecific fights between males occur every year, locked antlers are a fairly rare occurrence. But the two instances of interspecific locked antlers in Saskatchewan indicate that head-to-head encounters between males of the two species may occur in areas where both are fairly abundant. Such interactions between male mule and white-tailed deer could, of course, merely represent the release of high levels of aggression toward the nearest available moving object. (For example, various male ungulates during the rutting period have been known to charge people, automobiles or even freight trains.) However, the usual function of ritualized frontal encounters in conspecific male ungulates is to establish dominance, which results in reproductive advantage. If this drive is the explanation for mule deer-whitetail combats, then it suggests that Pleistocene differentiation of the two species from a common stock did not proceed as far as complete behavioural isolation.

These apparently reproductively related interactions do not necessarily indicate actual mating of the species, much less the production of viable hybrids in the wild. However, the two species are known to interbreed in captivity (Taylor, 1956).

\section{Acknowledgments}

I would like to thank Don Blood, DNR, for assistace in the writing and editing of the manuscript and Hugo Maliepaard, DNR, for translation of the Notz paper.

\section{LITERATURE CITED}

Hall, R. E., and K. R. Kelson. 1959. The mammals of North America. The Ronald Press Co. New York. Vol. II. 536 pp.

Nutz, F. W. 1965. Uber Verkampfen bei altund neuweltlichem. Schalenwild. Wild und Hund, $68: 71-73$.

Taylor, W. P. 1956. The deer of North America. The Stackpole Co. Harrisburg, Pa. and the Wildl. Mgmt. Inst. Washington, D.C.

Webb, S. B., G. Fitz, and M. Baker. 1958. Records of North American big game. Henry Holt and Co. Inc. New York. 264 pp.

\title{
POPULATION SIZE AND PRODUCTIVITY OF THE BLACK-TAILED PRAIRIE DOG IN SASKATCHEWAN
}

\author{
by Larry Kerwin, 905 McKinnon Drive, Calgary, Alberta
}

Despite the concern of conservationists little is known about the status of the black-tailed prairie dog (Cynomys ludovicianus ludovicianus) in Canada. Paynter (1962) estimated that there were 45,000 animals in eight colonies inhabiting some 2,400 acres. An investigation during 1970 (Kerwin and Scheelhaase, 1971) revealed 16 colonies with an estimated 10,823 animals occupving about 1,244 acres. Some additional information is now available on the status of this species in southwestern Saskatchewan.

\section{METHODS}

Colonies were located during the summers of 1970 and 1971 and their location plotted on a 1:50,000 topographical map. The area of each colony was determined by planimeter. Several representative colonies were counted twice a week in both May and July to determine the breeding 
population and to evaluate productivity. The rodents were counted either in early morning or late evening with the use of a $20-60 \mathrm{X}$ spotting scope. Litter sizes were determined by counting the number of young prairie dogs assembled at burrows.

\section{RESULTS}

\section{(a) Colony Formation}

In addition to the 16 prairie dog colonies found in 1970 (Kerwin and Scheelhaase, 1971), one new colony was discovered in 1971 in the NE1/4 Section 13 of 2-12-W3. This colony ("O") was less than 1 acre in size and had 11 burrows. Four adult animals were observed in the colony which was not begun until the fall of 1970 or the spring of 1971. I first observed the colony on April 5, 1971 and I know that it did not exist before September 1, 1970. Colony $O$ is 1.9 miles from the nearest colony. Nelson (1930) reports the establishment of new colonies as far as six miles from other towns, although Reid (1954) found that 1.5 to 2.0 miles was a more usual distance. Koford (1958) states that even at a favourable site within dispersal range of a thriving dog town, there is little chance that a new dog town will spring up.

\section{(b) Population Census}

Colonies G, I, and N were selected for population census during 1971 . The total population for each colony was determined by averaging a number of censuses (Table 1) and the corresponding density was then calculated using this data. Population densities ranged from 0.9 to 3.8 animals per acre in the three colonies counted. King (1955) had reported an average July density in South Dakota to be 8.7 animals per acre; using this figure, Kerwin and Scheelhaase (1971) estimated the Saskatchewan population to be 10,823 animals. If a density of 3.8 animals per acre is used to calculate the total population, the figure would be about 4,730 animals, a number which is well below previous estimates.

\section{(c) Litter Size}

Litter sizes can be determined by counting embryos, placental scars or corpora lutea. A fourth method is to count the number of young prairie dogs at burrows. If the holes are far apart, this method is reliable for about two weeks after the young emerge (Koford, 1958).

In this study, mean litter size was determined by counting the young.

Table 1. Summary of population counts and corresponding densities of three prairie dog colonies during 1971.

\begin{tabular}{|c|c|c|c|c|c|}
\hline Colony & Area (acres) & $\begin{array}{l}\text { Total } \\
\text { May }\end{array}$ & $\begin{array}{r}\text { Population } \\
\text { July }\end{array}$ & $\begin{array}{r}\text { Density } \\
\text { May }\end{array}$ & $\begin{array}{c}\text { (No. per acre) } \\
\text { July }\end{array}$ \\
\hline G & 85 & $211(5) *$ & $322(3)$ & 2.5 & 3.8 \\
\hline I & 110 & $247(3)$ & $265(3)$ & 2.2 & 2.4 \\
\hline $\mathrm{N}$ & 300 & $284(2)$ & - & 0.9 & - \\
\hline
\end{tabular}

* Number in parentheses indicates the total number of counts made during that month.

Table 2. The mean litter size for three prairie dog colonies during 1970 and 1971.

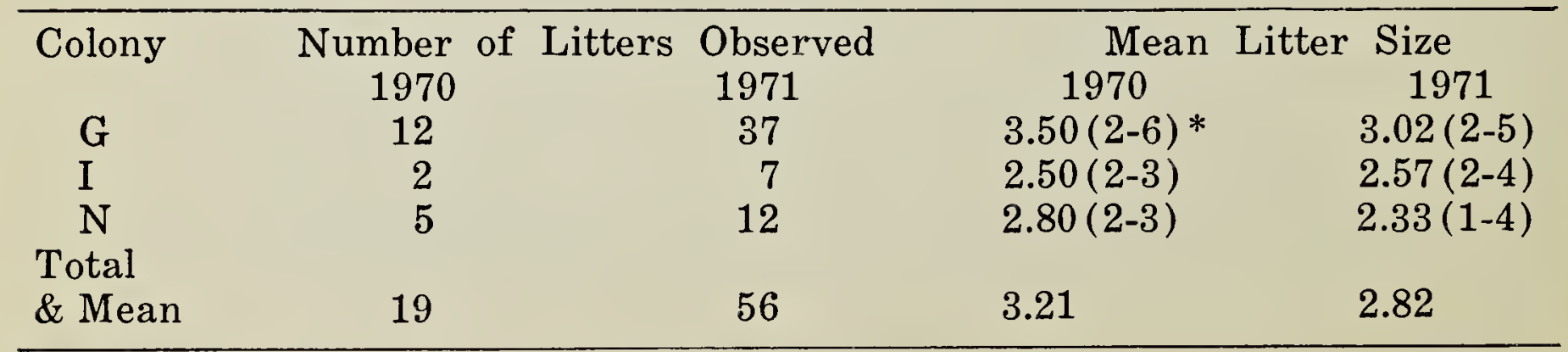

* Number in parentheses indicates the range. 
Mean litter size varied from 2.33 to 3.50 among the three colonies counted (Table 2). The largest litter observed was six. Other data on litter size for prairie dogs ranges from 4.1 in Colorado (Koford, 1958) to 5.0 in Kansas (Wade, 1928). These averages, however, were determined from embryo and corpora lutea counts and so are not directly comparable to the data in this study.

\section{CONCLUSION}

Since the black-tailed prairie dog is considered to be an endangered Canadian mammal (Novakowski, 1970), it is important that a more intensive study be carried out on the status and ecology of this species. It would appear from our results that there are even fewer prairie dogs existing in Canada than was previously supposed.

\section{LITERATURE CITED}

Kerwin, M. L., and C. G. Scheelhaase. 1971. Present status of the black-tailed prairie dog in Saskatchewan. Blue Jay, $29: 35-37$.

King, J. 1955. Social behavior, social organization, and population dynamics in a blacktailed prairie dog town in the Black Hills of South Dakota. Contrib. Lab. Vert. Biol. 67. Univ. Michigan, Ann Arbor.

Koford, C. B. 1958. Prairie dogs, whitefaces, and blue gramma. Wildlife Monograph No. 3, The Wildlife Society, Washington, D.C.

Nelson, E. W. 1930. Wild animals of North America. Nat. Geog. Society, Washington, D.C.

Novakowski, N. S. 1970. Endangered Canadian mammals. Can. Field-Nat., $84: 17-23$.

Paynter, E. L. 1962. The black-tailed prairie dog in Canada. Blue Jay, $20: 124-125$.

Reid, N. J 1954. The distribution of the black-tailed prairie dog in the badlands of southwestern North Dakota. Unpubl. M. S. Thesis, State Univ. Iowa, Iowa City.

Wade, O. 1928. Notes on the time of breeding and the number of young of Cynomys ludovicianus. Journ. Mamm., 9:149-151.

\section{SCORPIONS IN SASKATCHEWAN}

\section{by Donald J. Buckle, R.R. 1, Preeceville, Saskatchewan}

While scorpions are typically warmclimate animals, one small species, Vejovis boreus (Girard), extends north into western Canada. Gertsch and Soleglad (1966. The scorpions of the Vejovis boreus group in North America. Amer. Mus. Nov. 2278:1-54) recorded it from several localities in the prairie region of southern Alberta and in the lower Okanagan Valley of British Columbia. As habitats in southwestern Saskatchewan are very similar to those in southern Alberta, it seemed probable that $V$. boreus also occurred there and inquiries were made to those institutions likely to have material from the province and to a number of local naturalists.

No specimens were located but two sightings came to light. Harvey Beck (personal communication: 1970) told of seeing a scorpion near Minton, Saskatchewan in 1964. G. S. McLean of Eston, Saskatchewan, whom I contacted through the assistance of Ronald Hooper, reported (personal sommunication: 1970) the following incident which took place $3 / 4$ mile north of the Lancer Ferry on March 30,1963 . This incident is additionally interesting because it provides some information on the little known hiber- nation behaviour of the species:

"My son and his chum were digging a cave in one of the high cliffs. The cliff was sloping $3 / 4$ of the way up so that they had a footing where they were digging. They had dug back about six feet and they asked me to help them. About the first shovel full I sliced off in the very fine sandy soil I severed a little tunnel about the size of my small finger. The next slice in, four little creatures about the size of cockroaches dropped out. They apparently were hibernating. Having visited in Africa and seen scorpions I immediately recognized what they were...

The scorpions were given to the Biology Department of the University of Saskatchewan at Saskatoon where they seem to have been misplaced or lost. A search of the Department's invertebrate collection in 1970 failed to locate them.

Further reports are necessary to establish the distribution of $V$. boreus in Saskatchewan and the rest of western Canada. I would greatly appreciate receiving specimens or data. 